\title{
Sward structure and ingestive behavior of cows in tropical pastures managed under different forage allowances
}

[Estrutura do dossel forrageiro e comportamento ingestivo de vacas

\author{
E.R. Janusckiewicz ${ }^{1}$, D.R. Casagrande ${ }^{2}$, E. Raposo ${ }^{1}$, \\ C. Bremm ${ }^{3}$, R.A. Reis ${ }^{4}$, A.C. Ruggieri ${ }^{4}$ \\ ${ }^{1}$ Autonôma - Aquidauana, MS \\ ${ }^{2}$ Universidade Federal de Lavras - Lavras, MG \\ ${ }^{3}$ Pecuária e Desenvolvimento Rural- Porto Alegre, RS \\ ${ }^{4}$ Universidade Estadual Paulista - Jaboticabal, SP
}

\begin{abstract}
This study evaluated how changing the structure of Brachiaria brizantha cv. Marandu pasture under different forage allowances (FA) of 4, 7, 10 and $13 \mathrm{~kg} \mathrm{DM} / 100 \mathrm{~kg}$ BW (body weight) affected animal behavior over a two-year evaluation period. The experiment was conducted as a randomized block design with three replications (paddock). Sward height, total forage, and stem mass were lower for pastures managed with lower FA. Lower leaf mass was observed for lower FA in the second year. In hand-plucked samples, leaf and stem percentages remained unchanged in the morning but leaf percentage increased while stems decreased in the afternoon. Permanence time decreased linearly with increasing FA. In turn, a quadratic effect was observed for displacement rate. The bite rate was similar among different FAs. The results demonstrate that FA varying between 7 and $10 \mathrm{~kg} \mathrm{DM} / 100 \mathrm{~kg} \mathrm{BW}$ are more suitable to balance the amounts of leaves and stems in the sward. The studied FA levels do not limit forage availability. Permanence time decreases and displacement rate increases as FA increases.
\end{abstract}

Keywords: bite rate, displacement, forage mass, sward height

\section{RESUMO}

O objetivo foi avaliar como mudanças na estrutura de pastos de Brachiaria brizantha cv. Marandu, sob diferentes ofertas de forragem $(\mathrm{OF})$ de 4, 7, 10 e 13kg MS/100kg PC, afetam o comportamento animal durante um período de avaliação de dois anos. O delineamento utilizado foi em blocos ao acaso, com três repetições (piquetes). A altura do dossel, a massa de forragem total e de colmos foram menores em pastos manejados com menores OF. A menor massa de folhas foi observada na menor OF no segundo ano. Nas amostras de pastejo simulado, as porcentagens de folhas e colmos não diferiram pela manhã, mas a porcentagem de folhas aumentou, enquanto a de colmos diminuiu à tarde. $O$ tempo de permanência dos animais diminuiu linearmente com o aumento das OF. Efeito quadrático foi observado para taxa de deslocamento. A taxa de bocados foi similar entre as OF. Os resultados demonstram que variar as OF entre 7 e 10kg MS/100kg PC é mais adequado para balancear as quantidades de folhas e colmos no dossel forrageiro. Os níveis de OF estudados não limitam a forragem disponível. O tempo de permanência diminuí e a taxa de deslocamento aumenta com o aumento das $O F$.

Palavras-chave: altura, deslocamento, massa de forragem, taxa de bocados

Recebido em 29 de junho de 2018

Aceito em 25 de janeiro de 2019

E-mail: estella_rosseto_janusckiewicz@yahoo.com.br 


\section{INTRODUCTION}

Grazing is the most economical way of feeding ruminants, but using forage efficiently requires adequate pasture management and extensive knowledge on soil, plant, animal, and climate interface relationships. The efficient use of forage results in economically competitive cost of animal production without damaging pasture productivity. Therefore, it is necessary to know how the sward structure responds to the environment and the used management technique. Thus, plant quantity and morphological components determine the amount of forage available, and how it is presented to the animal.

Sward structure is directly affected by the pasture management. There are different pasture management methods based on characteristics such as sward height, forage mass, stocking rate and light interception, among others. An option is to base the management on forage allowance (FA). FA is a function of the interrelationships between forage mass and stocking rate and can be a powerful tool for explaining differences in animal performance (Sollenberger et al., 2005). Studies with tropical grasses performed to evaluate the effects of FA have resulted in a better understanding of the response of forage crops and animals to changing grazing intensity (Reis et al., 2013).

Variable FA changes grazing intensities, resulting in different sward structures that can be detected by observing the patterns of animal ingestive behavior (Mezzalira et al., 2012). Grazing animals perform many activities and if total grazing time was to increase for any reason such as low FA, for example, the time available for other activities is expected to decrease proportionally (Carvalho et al., 2001). Displacement rate presented a positive linear relationship with the daily displacement and grazing time while the incremental change in the daily grazing time was accompanied by an increase in the daily displacement (Trindade et al., 2012). The interdependence between pasture structure and the ingestive behavior of grazing animals is important and well known. Considering this fact, the present study investigates how the different FAs (4, 7, 10 and $13 \mathrm{~kg} \mathrm{DM} / 100 \mathrm{~kg} \mathrm{BW}$ ) change the structure of tropical grass (Brachiaria brizantha cv.
Marandu) pastures managed under rotational grazing system and affect the ingestive behavior of dairy cows.

\section{MATERIALS AND METHODS}

The study was carried out during the rainy season for two years, from December 2005 to March 2006 (first year) and December 2006 to March 2007 (second year). The experiment was conducted in Jaboticabal, northeastern Sao Paulo State, Brazil, at $21^{\circ} 14^{\prime} 05^{\prime \prime S}, 48^{\circ} 17^{\prime} 09^{\prime \prime} \mathrm{W}$, and $615 \mathrm{~m}$ above sea level. The pastures were established in 2001 in a clayey Oxisol (Natural..., 2010) using Brachiaria brizantha cv. Marandu [(Hochst. ex A. Rich.) Stapf. syn. Urochloa brizantha cv. Marandu (Hochst. ex A. Rich.) R.D. Webster]. The region climate is classified as megathermal tropical savanna climate, with dry winter and hot and rainy summer (Aw), according to Köppen. The average temperatures and precipitations were $23.5^{\circ} \mathrm{C}$ and $242.6 \mathrm{~mm}, 25.0^{\circ} \mathrm{C}$ and $237.0 \mathrm{~mm}$, $24.2^{\circ} \mathrm{C}$ and $416.4 \mathrm{~mm}, 24.5^{\circ} \mathrm{C}$ and $136.9 \mathrm{~mm}$, for December, January, February and March, respectively, in the first year and $24.4^{\circ} \mathrm{C}$ and $221.0 \mathrm{~mm}, 23.9^{\circ} \mathrm{C}$ and $644.6 \mathrm{~mm}, 24.4^{\circ} \mathrm{C}$ and $154.7 \mathrm{~mm}, 24.9^{\circ} \mathrm{C}$ and $156.3 \mathrm{~mm}$ for the same months in the second year.

The chemical characteristics of the soil (upper layer, $0-20 \mathrm{~cm}$ ) in the first year were: $\mathrm{pH}, 5.2$; organic matter, $25 \mathrm{~g} / \mathrm{dm}^{3}$; phosphorus in resin, $12 \mathrm{mg} / \mathrm{dm}^{3}$; potassium, $5.3 \mathrm{mmol}_{\mathrm{c}} / \mathrm{dm}^{3}$; calcium, $27.4 \mathrm{mmol}_{\mathrm{c}} / \mathrm{dm}^{3}$; magnesium, $13.7 \mathrm{mmol}_{\mathrm{c}} / \mathrm{dm}^{3}$; and base saturation of $59.6 \%$. In the second year, the soil parameters were: $\mathrm{pH}, 5.3$; organic matter, $23 \mathrm{~g} / \mathrm{dm}^{3}$; phosphorus in resin, $19 \mathrm{mg} / \mathrm{dm}^{3}$; potassium, $\quad 4.3 \mathrm{mmol}_{\mathrm{c}} / \mathrm{dm}^{3}$; calcium, $33.2 \mathrm{mmol}_{\mathrm{c}} / \mathrm{dm}^{3}$; magnesium, $17 \mathrm{mmol}_{\mathrm{c}} / \mathrm{dm}^{-3}$; and base saturation of $62.5 \%$. Based on the soil analysis, maintenance fertilization for Marandu grass consisted of applying 140, 30, and $100 \mathrm{~kg} / \mathrm{ha} /$ year of $\mathrm{N}, \mathrm{P}_{2} \mathrm{O}_{5}$, and $\mathrm{K}_{2} \mathrm{O}$ in the first year and 100,60 , and $80 \mathrm{~kg} / \mathrm{ha} /$ year in the second. The fertilizers used were urea (divided in two applications), superphosphate, and potassium chloride.

Treatments consisted of four FA levels (green leaf and stem) on dry matter basis corresponding to $4,7,10$, and $13 \mathrm{~kg} \mathrm{DM} / 100 \mathrm{~kg} \mathrm{BW}$. The completely randomized block design consisted of four treatments and three replications 
(paddocks). The experimental area consisted of a $4,896 \mathrm{~m}^{2}$ pasture, which was divided into 12 paddocks of 229.5, 408, 408 and $586.5 \mathrm{~m}^{2}$ for 4 , 7 , 10 , and $13 \mathrm{~kg} \mathrm{DM} / 100 \mathrm{~kg} \mathrm{BW}$, respectively. The lowest FA treatments were established in the smallest paddocks, and vice versa. Paddock size was modified so that the number of tester animals was similar to avoid interference on grazing behavior. These animals were divided into groups according to live weight and available dried forage mass, to obtain a similar total number of animals grazing in the rotationally stocked experimental units. The mob stocking method was used (Allen et al., 2011), totaling four grazing cycles of 8 hours occupancy and 21 days rest off each year. Female, nonlactating Holstein cows weighing $450 \mathrm{~kg}$ on average grazed the paddocks.

Forage mass was evaluated using a double sampling method (Sollenberger and Cherney, 1995). The sward height was measured in 50 points and used to determine average compressed heights. Forage samples were cut at the ground level, weighed and separated into leaves and stems, and dried $\left(55^{\circ} \mathrm{C}\right.$ for $\left.72 \mathrm{~h}\right)$. Regression equations were obtained to estimate forage mass. Stocking rate was adjusted considering forage mass, paddock area, and pre-set FA. In addition, 50 readings with the graduated stick were also performed to determine average sward height. Forage mass and morphological components were determined by the weights of the dried subsamples collected at average heights. These calculations were performed for each treatment, grazing cycle, and year, under pre-grazing conditions.

During grazing cycles in the first year, forage samples were hand-plucked (Sollenberger and Cherney, 1995). While monitoring one animal of each plot in two day-shifts (morning and afternoon), the grass samples were collected by hand to obtain material most similar to that selected by the animals. Then, the samples were weighed and separated into leaves and stems, and dried $\left(55^{\circ} \mathrm{C}\right.$ for $\left.72 \mathrm{~h}\right)$. Permanence time and displacement rate were measured during the whole time the animals occupied the paddocks. For these evaluations, all paddocks were divided into $3 \mathrm{~m} \times 3 \mathrm{~m}$ quadrants and three animals were observed in each plot, totaling nine animals per treatment per grazing cycle. Quadrant divisions were marked on the fences around the paddocks and within the paddocks, the division was imaginary following the markings of the fences. Each quadrant was considered as one grazing site. Permanence time was defined as the average time spent grazing in each quadrant per day and displacement rate, the number of displacements per day. Occupancy period in the paddocks was divided into two-day shifts. Bite rate of animals was also evaluated in the morning in all grazing cycles in the first year. Three animals from each paddock were observed, totaling nine animals per treatment per grazing cycle. Evaluations were performed at the same time in each paddock.

The data on the structural characteristics were analyzed using the Mixed procedure of SAS (Statistical..., 2010) and orthogonal polynomial contrasts were used for level comparisons (Littel et al., 2006). To evaluate the grazing cycle and year effects, the results were analyzed by Tukey test and the FA effect by linear regression up to third order, both at 5\% significance. Behavior data for each block represented the average of three tester animals, totaling nine values per treatment per grazing cycle. In the ANOVA model, the FA and grazing cycle (repeated measures in time) were considered as fixed effects while the interactions between FA and grazing cycle and block were considered random effects. For the permanence time and displacement rate, the fixed effects of evaluated day shift and the interaction with FA were also included. All behavioral variables had normal distribution (Kolmogorov-Smirnov test, P> 0.05). Data were submitted to polynomial regression analysis at $5 \%$ significance. The equation with the highest coefficient of determination $\left(\mathrm{R}^{2}\right)$ was chosen. Pearson correlation analysis was performed $(\mathrm{P}<0.05)$ among behavioral variables and morphological composition variables of hand-plucked samples.

\section{RESULTS AND DISCUSSION}

Increased FA modified $(\mathrm{P}<0.05)$ the sward height, total forage and stem masses (Table 1). No interaction was observed among FA, year, and grazing cycle ( $\mathrm{P}>$ 0.05). However, increasing FA caused the sward height to increase linearly and had a quadratic effect on stem and forage masses, which increased until reaching the highest values for intermediary FA, peaking at $9.13 \mathrm{~kg} \mathrm{DM} / 100 \mathrm{~kg} \mathrm{BW}$. After 
reaching the highest FA, forage mass decreased. Thus, the pastures managed with higher FA displayed higher sward heights and decreased forage mass.

Forage mass was higher $(\mathrm{P}>0.05)$ in the first year $(7583.8 \mathrm{~kg} \mathrm{DM} / \mathrm{ha})$ compared to the second $(5686.2 \mathrm{~kg} \mathrm{DM} / \mathrm{ha})$. In relation to the experimental period, forage mass increased with advanced grazing cycles from 5870 to 6632 and then to $7403 \mathrm{~kg} \mathrm{DM} / \mathrm{ha}$ for the first, second and third grazing cycles, respectively. Sward height varied $(\mathrm{P}<0.05)$ according to the interaction between years and grazing cycles. In the last grazing cycle of the first year, sward height was higher $(\mathrm{P}<0.05)$ while the heights were similar (P> 0.05) for all grazing cycles in the second year. Comparison between years showed that height differed $(\mathrm{P}<0.05)$ only in the third grazing cycle and was taller in the first year. Stem mass was affected only by the year $(\mathrm{P}<$ $0.05)$.

Table 1. Sward height $(\mathrm{cm})$, forage and stem masses $(\mathrm{kg} \mathrm{DM} / \mathrm{ha})$ of Marandu grass managed under forage allowances

\begin{tabular}{|c|c|c|c|c|c|c|c|c|}
\hline \multirow{2}{*}{ Variables } & \multicolumn{4}{|c|}{ Forage allowance } & \multirow{2}{*}{$\begin{array}{l}\text { Standard } \\
\text { deviation }\end{array}$} & \multicolumn{3}{|c|}{$\mathrm{P}$ value } \\
\hline & 4 & 7 & 10 & 13 & & $\mathrm{~L}$ & Q & C \\
\hline Sward height & 20.7 & 27.6 & 26.0 & 30.7 & 1.77 & 0.011 & 0.570 & 0.113 \\
\hline Forage mass & 5876 & 7025 & 7165 & 6475 & 224.14 & 0.126 & 0.009 & 0.876 \\
\hline Stem mass & 2540 & 3192 & 3297 & 3183 & 140.35 & 0.018 & 0.034 & 0.620 \\
\hline
\end{tabular}

L, Q and C - linear, quadratic and cubic order of forage allowance effect

Equations - Sward height: $y=0.9467 x+18.203$; Forage mass: $y=-51.083 x^{2}+932.98 x+2970.4$; Stem mass: $y=-$ $21.278 \mathrm{x}^{2}+429.52 \mathrm{x}+1178.8$

The swards managed with lower FA might not have reached this critical point, and therefore, the taller pastures resulting from higher FA were especially due to stem elongation (Table 1). As the FA increased, the grazing intensity decreased while the amount of material remaining after grazing increased. This result can be explained by the fact that the amount of forage provided is more than the animal may consume in higher FA. Paula et al. (2012) studied Marandu grass submitted to grazing intensities of 15,30 , and $45 \mathrm{~cm}$ and reported that the FA decreased as the intensity of grazing increased, and pastures managed with $15 \mathrm{~cm}$ had higher nutritional value and sward structure more favorable to forage apprehension by animals.

As a result of post-grazing residue, the remaining plants competed for light to continue the photosynthetic process, thus elongating the stem toward the top of the sward, increasing sward height and, consequently, this component mass. So, pastures managed with FA between 7 and $10 \mathrm{~kg} \mathrm{DM} / 100 \mathrm{~kg} \mathrm{BW}$ and 21 rest days intercepted $95 \%$ of incoming radiation, while the swards managed with lower and higher FA intercepted less and close to $100 \%$ of incoming radiation, respectively. Therefore, it is possible that pastures managed with higher FA had increased senescence, which explains the observed decreasing trend of the forage (Table 1) and leaf masses (Table 2). Simultaneously, Casagrande et al. (2010) observed a $44 \%$ increase of senescence rate as FA increased from 4 to $13 \mathrm{~kg} \mathrm{DM} / 100 \mathrm{~kg} \mathrm{BW}$. It is also possible that the increased competition for light among tillers in taller swards reduces tiller density and renewal rate (Cutrim Junior et al., 2011).

Table 2. Leaf (kg DM/ha) mass of Marandu grass managed under forage allowances

\begin{tabular}{|c|c|c|c|c|c|c|c|c|}
\hline \multirow{2}{*}{ Year } & \multicolumn{4}{|c|}{ Forage allowances } & \multirow{2}{*}{ Standard deviation } & \multicolumn{3}{|c|}{$\mathrm{P} *$ value } \\
\hline & 4 & 7 & 10 & 13 & & $\mathrm{~L}$ & $\mathrm{Q}$ & $\mathrm{C}$ \\
\hline First & $2258 \mathrm{~A}$ & $2513 \mathrm{~A}$ & $2101 \mathrm{~A}$ & $2253 \mathrm{~A}$ & & 0.479 & 0.700 & 0.073 \\
\hline Second & $1221 \mathrm{~B}$ & $1724 \mathrm{~B}$ & $1849 \mathrm{~A}$ & $1628 \mathrm{~B}$ & 111.04 & 0.137 & 0.048 & 0.972 \\
\hline
\end{tabular}

Means followed by the same letter in the column do not differ by Tukey at $5 \%$

$\mathrm{L}, \mathrm{Q}$, and $\mathrm{C}$ - linear, quadratic and cubic order of forage allowance effect

Equation - Leaves mass (second year): $\mathrm{y}=-20.111 \mathrm{x}^{2}+386.76 \mathrm{x}-2.6444$ 
As forage and stem mass increased, the leaf mass also increased as grazing cycles advanced. Leaf mass was higher $(\mathrm{P}<0.05)$ in the third cycle with values of 1749,1851 and $2231 \mathrm{~kg} \mathrm{DM} / \mathrm{ha}$ in the grazing cycles 1,2 and 3, respectively. Leaf mass did not change in response to FA $(\mathrm{P}>0.05)$ in the first year (Table 2). There was, however, a significant interaction between FA and year $(\mathrm{P}<$ $0.05)$. In the second year, a quadratic association was observed, and leaf mass increased for FA up to $10 \mathrm{~kg} \mathrm{DM} / 100 \mathrm{~kg} \mathrm{BW}$ and decreased as FA increased further peaking at $9.62 \mathrm{~kg} \mathrm{DM} / 100 \mathrm{~kg}$ $\mathrm{BW}$. Leaf mass was higher in the first year for FAs 4,7 and $13 \mathrm{~kg}$ DM/100kg BW, when comparing the two experimental years.

Forage mass was $1897.6 \mathrm{~kg} \mathrm{DM} / \mathrm{ha}$ in the first year and greater than in the second, probably due to the higher leaf mass observed in the first year compared to the second (Table 2). In addition, the management was probably more efficient to control the stem accumulation, which was $2224 \mathrm{~kg} \mathrm{DM} / \mathrm{ha}$ in the second year compared to $3882 \mathrm{~kg} \mathrm{DM} / \mathrm{ha}$ in the first year. This difference between the characteristics in the two years can be a result of the time needed for implementing the treatments. After a year of the FA imposition on the pastures, the management controlled more effectively the response variables such as sward height, leaf, and stem masses, and forage senescence.

Leaf, stem, and forage masses increased as grazing cycles advanced due to the accumulating material that was not consumed by the animals during the experimental period coupled with the increasing number of reproductive tillers in late summer (Casagrande et al., 2010), characteristic of Brachiaria grass. This fact can reduce grazing efficiency and consequently increase both forage excess and mass in the subsequent grazing cycle. Comparison between the years showed that the sward heights differed only in the third grazing cycle while the higher values in the first year were due to the higher stem accumulation in this year, which caused a gradual height increase as grazing cycles advanced.

There was an interaction between FA and evaluated day shift $(\mathrm{P}<0.05)$ in hand-plucked forage samples (Table 3). Percentages of leaves and stems did not change with FA $(\mathrm{P}>0.05)$ in the morning, indicating no restriction on animal consumption, i.e., no FA limited the amount of forage available to animals earlier in the day. In the afternoon, following the quadratic effect, the leaf percentage decreased for FA $7 \mathrm{~kg} \mathrm{DM} / 100 \mathrm{~kg}$ BW and increased for FA $13 \mathrm{~kg} \mathrm{DM} / 100 \mathrm{~kg}$ BW. Inverse behavior was observed for stem percentages. Samples from FA $13 \mathrm{~kg}$ DM/100kg BW had increased leaf $(91.2 \%)$ and decreased stem $(8.7 \%)$ percentages. The low-intensity grazing permitted the animals to select the leaves to be consumed in this FA. The found morphological composition is similar to the $91.9 \%$ of leaves and $4.9 \%$ of stems observed in the hand-plucked samples of Marandu grass managed under four sward heights $(10,20,30$ and $40 \mathrm{~cm})$ as reported by Silva et al. (2013).

Table 3. Percentages of leaves and stems in hand-plucked samples of Marandu grass managed under forage allowances and grazed by dairy cows

\begin{tabular}{|c|c|c|c|c|c|c|c|c|}
\hline \multirow[b]{2}{*}{ Time of day } & \multicolumn{4}{|c|}{ Forage allowance } & \multirow{2}{*}{ Standard deviation } & \multicolumn{3}{|c|}{$\mathrm{P}$ value } \\
\hline & 4 & 7 & 10 & 13 & & $\mathrm{~L}$ & $\mathrm{Q}$ & $\mathrm{C}$ \\
\hline \multicolumn{5}{|c|}{ Leaves } & & & & \\
\hline Morning & $88.6 \mathrm{~A}$ & $87.6 \mathrm{~A}$ & $89.1 \mathrm{~A}$ & $85.9 \mathrm{~A}$ & \multirow{2}{*}{4.44} & 0.311 & 0.435 & 0.293 \\
\hline Afternoon & $\begin{array}{l}87.8 \mathrm{~A} \\
\text { Stems }\end{array}$ & $83.5 \mathrm{~A}$ & $87.9 \mathrm{~A}$ & $91.2 \mathrm{~A}$ & & 0.027 & 0.007 & 0.106 \\
\hline Morning & $11.4 \mathrm{~A}$ & $12.3 \mathrm{~A}$ & $10.9 \mathrm{~A}$ & $14.0 \mathrm{~A}$ & \multirow{2}{*}{4.44} & 0.311 & 0.435 & 0.293 \\
\hline Afternoon & $12.1 \mathrm{~A}$ & $16.5 \mathrm{~A}$ & $12.1 \mathrm{~A}$ & $8.7 \mathrm{~A}$ & & 0.027 & 0.007 & 0.106 \\
\hline
\end{tabular}

Means followed by the same letter in the column do not differ by Tukey test at $5 \%$

$\mathrm{L}, \mathrm{Q}$ and $\mathrm{C}$ - linear, quadratic and cubic order of forage allowance effect

Equations - Leaves: $\mathrm{y}=0.213 \mathrm{x}^{2}-3.12 \mathrm{x}+96.41 ;$ Stems: $\mathrm{y}=-0.213 \mathrm{x}^{2}+3.12 \mathrm{x}+3.58$

Data from the FA $7 \mathrm{~kg}$ DM/100kg BW samples collected in the afternoon showed leaf reduction and an increment of the stem fraction (Table 3), so that more new leaves were produced during the rest period in this FA. The animals select leaves preferably when feeding and new leaves were consumed in the morning leaving the older leaves and stems to be consumed in the 
afternoon. Also, the analyzed data are averages from different grazing cycles and, in the last, the stems had inflorescences which, in the morphological separation, were left/grouped with the stems (inflorescences were considered as stems). Therefore, we can conclude that the increased stems in the hand-plucked samples of the FA $7 \mathrm{~kg}$ DM/100kg BW resulted from the inflorescence that was selected by grazing animals.

There was no effect of the interaction between FA and evaluated day shift $(\mathrm{P}>0.05)$ nor day- shift effect on displacement rate and permanence time (Table 4). Permanence time decreased as FA increased (Table 4) demonstrating that the animals spent more time moving in reduced FA. For FA $4 \mathrm{~kg} \mathrm{DM} / 100 \mathrm{~kg} \mathrm{BW}$, the largest grazing intensity resulted in lower forage mass (Table 1), which led the animals to move more looking for better feeding stations to compensate the low amount of available forage. Mezzalira et al. (2012) verified that grazing time increased as FA decreased in native pasture and most of the increased time was devoted to harvesting.

Table 4. Permanence time (minutes), displacement rate (number) and bite rate (bites/ minutes) of dairy cows grazing Marandu grass managed under forage allowances

\begin{tabular}{|c|c|c|c|c|c|c|c|c|}
\hline \multirow{2}{*}{ Variables } & \multicolumn{4}{|c|}{ Forage allowance } & \multirow{2}{*}{$\begin{array}{l}\text { Standard } \\
\text { deviation }\end{array}$} & \multicolumn{3}{|l|}{$\mathrm{P}$ value } \\
\hline & 4 & 7 & 10 & 13 & & $\mathrm{~L}$ & Q & $\mathrm{C}$ \\
\hline Permanence time & 7.5 & 6.1 & 6.5 & 5.7 & 1.63 & 0.003 & 0.451 & 0.468 \\
\hline Displacement rate & 46.3 & 64.8 & 65.6 & 69.2 & 15.95 & $<0.001$ & 0.023 & 0.158 \\
\hline Bite rate & 35.3 & 38.1 & 36.9 & 39.1 & 5.73 & 0.187 & 0.867 & 0.326 \\
\hline
\end{tabular}

$\mathrm{L}, \mathrm{Q}$ and $\mathrm{C}-$ linear, quadratic and cubic order of forage allowance effect

Equations - Permanence time: $y=-0.164 x+7.83$; Displacement rate: $y=-0.412 x^{2}+9.32 x+16.62$

Increased FA and decreasing grazing intensity caused the animals to spend more time in each feeding station, thus reducing permanence time and increasing displacement rate. This is because the bits become larger and the animal searches for more leaves. With low competition in high FA, the animals moved more often searching sites with abundant leaves, decreasing the permanence in each site. On the order hand, under lower FA, the animals changed the grazing site less frequently to explore each one longer, so that permanence time in each grazing site increased with decreasing FA. Palhano et al. (2006) found that movement paths increased with sward increasing height, but total displacement decreased when evaluating displacement and forage searching patterns of Holstein heifers in Mombasa grass pasture.

The higher the forage mass, the more selective the animals become. So, probably in FA 7 and $10 \mathrm{~kg} \mathrm{DM} / 100 \mathrm{~kg} \mathrm{BW}$, the animals had greater opportunity to apprehend leaves of optimal sward height. In addition, higher FA decreased competition among animals while searching for better feeding stations, and in the pasture it increased the displacement rate (Table 4). As previously mentioned, only displacement related to forage ingestion was considered. Additionally, we must remember that the animals were taken to the stockyard during the periods of activities such as rumination or idleness, i.e., at the hottest period of the day (from 11:00am to 3:00pm). Segabinazzi et al. (2014) studied Holstein calves in feedlot and pasture and observed adaptive differences between animals in two husbandry systems regarding feeding and rumination, mainly during the hottest hours of the day. According to these authors, the feeding activity oscillated throughout the day, with the highest concentration at $4: 00 \mathrm{pm}$ (two hours after supplement supply) and the rumination, between 1:00 and 2:00pm (when more than $50 \%$ of the animals were observed in this activity). Ruminants can have between three and five daily grazing events while the major ones occur early morning and late afternoon/early evening (Gregorini, 2012).

The bite rate was similar $(\mathrm{P}>0.05)$ between FAs, averaging 37.3 bites/minute. Both the leaf mass (Table 2) in the first year and leaf percentages in hand-plucked samples (Table 3) in the morning did not change $(\mathrm{P}>0.05)$ with FA. As the leaf amount was not limiting to the consumption in the different FAs, the bite rate was similar (P> 0.05) among them (Table 4). It is important to mention that bite rates were measured early morning when the forage mass was similar in all treatments. Silva et al. (2013) reported that the 
animals increased their bite rates to compensate for the smaller bite mass while also increasing the grazing time for the $10 \mathrm{~cm}$ sward height. These authors reported a bite rate of 46.3 and 17.5 bites/minute and grazing time between 684 and 630 minutes on swards managed at 10 and $40 \mathrm{~cm}$, respectively.

Forage plants are the most important feed source for ruminant production while the Brachiaria cultivars are the most used in tropical environments. Besides, Carvalho et al. (2001) emphasized that the animal intake under grazing is a consequence of both the accumulation of forage consumed in each bite and the bite frequency during feeding time. Additionally, the stocking rate is linked to FA. Stocking density can influence how the animals respond to forage availability while low to moderate densities encourage selective grazing (Provenza et al., 2007). Typically, in tropical regions, the water amount and temperature in the summer periods are not limiting factors for forage production. Although the amount of available forage is always favorable even when apparently restricted, the quality of the material offered could become a limiting factor for animal performance or milk production.

\section{CONCLUSIONS}

FA levels varying between 7 and $10 \mathrm{~kg}$ $\mathrm{DM} / 100 \mathrm{~kg} \mathrm{BW}$ are more suitable to balance the amounts of leaves and stems in the sward; more specifically, 9.13 and $9.62 \mathrm{~kg} \mathrm{DM} / 100 \mathrm{~kg} \mathrm{BW}$ for forage and leave masses, respectively. The studied FA levels did not limit the forage available to grazing dairy cows and percentages of leaves in hand-plucked samples. Permanence time decreases and displacement rate increases as FA increases.

\section{ACKNOWLEDGMENTS}

The authors thank Universidade Estadual Paulista (UNESP/FCAV), Jaboticabal, SP, and the Postgraduate Program in Animal Science for offering the necessary conditions and the opportunity to do the work. We also thank Dr. José Alberto Gomide, retired professor at the Universidade Federal de Viçosa, MG, for his teachings and technical contribution.

\section{REFERENCES}

ALLEN, V.G.; BATELLO, C.; BERRETTA, E.J. et al. An international terminology for grazing lands and grazing animals. Grass Forage Sci., v.66, p.2-28, 2011.

CARVALHO, P.C.F.; RIBEIRO FILHO, H.M.N.; POLI, C.H.E.C. et al. Importância da estrutura da pastagem na ingestão e seleção de dietas pelo animal em pastejo. In: REUNIÃO ANUAL DA SOCIEDADE BRASILEIRA DE ZOOTECNIA, 38., 2001, Piracicaba. Anais... Piracicaba: [SBZ], 2001. v.1, p.853-871.

CASAGRANDE, D.R.; RUGGIERI, A.C.; JANUSCKIEWICZ, E.R. et al. Características morfogênicas e estruturais do capim-Marandu manejado sob pastejo intermitente com diferentes ofertas de forragem. Rev. Bras. Zootec., v.39, p.2108-2115, 2010.

CUTRIM JUNIOR, J.A.A.; CÂNDIDO, M.J.D.; VALENTE, B.S.M. et al. Características estruturais do dossel de capim-tanzânia submetida a três frequências de desfolhação e dois resíduos pós-pastejo. Rev. Bras. Zootec., v.40, p.489-497, 2011.

GREGORINI, P. Diurnal grazing pattern: its physiological basis and strategic management. Animal Prod. Sci., v.52, p.416-430, 2012.

LITTELL, R.C.; MILLIKEN, G.A.; STROUP, W.W. et al. SAS for mixed models. 2.ed. SAS Institute, Cary, NC, 2006. 813p.

MEZZALIRA, J.C.; BREMM, C.; TRINDADE, J.K. et al. The ingestive behavior of cattle in large-scale and its application to pasture management in heterogeneous pastoral environments. J. Agric. Sci. Tech., v.2, p.909916, 2012.

NATURAL Resources Conservation ServiceNRCS. Keys to soil taxonomy. 11.ed. Washington: United States Department of Agriculture, 2010. 346p.

PALHANO, A.L.; CARVALHO, P.C.F.; DITTRICH, J.R. et al. Padrões de deslocamento e procura por forragem de novilhas leiteiras em pastagem de capim-Mombaça. Rev. Bras. Zootec., v.35, p.2253-2259, 2006. 
PAULA, C.C.L.; EUCLIDES, V.P.B.; MONTAGNER, D.B. et al. Estrutura do dossel, consumo e desempenho animal em pastos de capim-marandu sob lotação contínua. Arq. Bras. Med. Vet. Zootec., v.64, p.169-176, 2012.

PROVENZA, F.D.; VILLALBA, J.J.; HASKELL, J.H. et al. The value to herbivores of plant physical and chemical diversity in time and space. Crop Sci., v.47, p.382-398, 2007.

REIS, R.A.; VALENTE, A.L.S.; SANTOS, S.M.C. et al. Performance of young Nelore bulls grazing Marandu grass pasture at different heights. Trop. Grassl. Forrajes Trop., v.1, p.114$115,2013$.

SEGABINAZZI, L.R.; MENEZES, L.F.G.; SILVA, C.E.K. et al. Diurnal ingestive behavior of Holstein calves reared in different systems: feedlot or pasture. Acta Sci. Anim. Sci., v.36, p.225-231, 2014.

SILVA, S.C.; GIMENES, F.M.A.; SARMENTO, D.O.L. et al. Grazing behaviour, herbage intake and animal performance of beef cattle heifers on Marandu palisade grass subjected to intensities of continuous stocking management. J. Agric. Sci., v.151, p.727-739, 2013.
SOLLENBERGER, L.E.; CHERNEY, D.J.R. Evaluating forage production and quality. In: BARNES, R.F.; MILLER, D.A.; NELSON, C.J. (Eds.). Forages: the science of grassland agriculture. Iowa: State University Press, 1995. p.97-110.

SOLLENBERGER, L.E.; MOORE, J.E.; ALLEN, V.G.; PEDREIRA, C.G.S. Reporting forage allowance in grazing experiments. Crop Sci., v.45, p.896-900, 2005.

STATISTICAL analysis system. Version 9.4. Cary: SAS Institute, 2010.

TRINDADE, J.K.; PINTO, C.E.; NEVES, F.P. et al. Forage allowance as a target of grazing management: implications on grazing time and forage searching. Rangeland Ecol. Manag., v.65, p.382-393, 2012. 